\title{
DETERMINAN PEMBIAYAAN MURABAHAH PADA UNIT USAHA SYARIAH: MODEL REGRESI PANEL
}

\author{
Ahmad Wahyudi \\ Universitas Muhammadiyah Prof. Dr. Hamka \\ ahmadwahyudi.aming@gmail.com
}

\begin{abstract}
.
Financing is one main activity in Islamic banking operations. The aim of this research is to determine the factors that influence the financing in Islamic business unit. This research is using panel regression with fixed effet model as a tool of analysis. The sample that used in this object is five Islamic business unit, such as Bank of BTN, Bank of Permata, Bank of CIMB Niaga, Bank of DKI, and Bank of West Kalimantan. The result shows that only deposit funds that have an influence to murabahah financing in Islamic business unit, otherwise the operational efficiency ratio (BOPO) doesn't have an impact on financing.
\end{abstract}

Keywords: murabahah financing; Islamic business unit; panel regression

\begin{abstract}
Abstrak.
Pembiayaan merupakan salah satu aktivitas pada operational perbankan syariah. Tujuan penelitian ini adalah untuk menentukan faktor-faktor apa saja yang mempengaruhi jumlah penyaluran pembiayaan pada unit usaha syariah. Penelitian ini menggunakan teknik analisis regresi panel dengan model efek tetap. Sampel yang dipergunakan adalah lima unit usaha syariah yaitu Bank BNT, Bank Permata, Bank CIMB Niaga, Bank DKI, dan Bank Kalimatan Barat. Hasil yang ada menunjukkan bahwa hanya dana pihak ketiga yang berpengaruh terhadap pembiayaan murabahah, sedangkan rasio efisiensi operasional yang diukur dengan rasio BOPO tidak memiliki pengaruh terhadap jumlah penyaluran pembiayaan.
\end{abstract}

Kata Kunci: pembiayaan murabahah; unit usaha syariah; regresi panel

Diterima: 15 Juni 2016; Direvisi: 30 Agustus 2016; Disetujui: 19 September 2016 


\section{PENDAHULUAN}

Perbankan syariah pada dasarnya merupakan pengembangan dari konsep ekonomi Islam, terutama dalam bidang keuangan yang dikembangkan sebagai suatu respon dari kelompok ekonom dan praktisi perbankan muslim yang berupaya mengakomodasi desakan dari berbagai pihak yang mengharapkan adanya jasa transaksi keuangan yang dilakukan sejalan dengan nilai moral dan prinsip-pronsip syariah. Karena dalam kenyataannya untuk menghadapi gejolak moneter yang diwarnai dengan tingkat suku bunga tinggi perbankan syariah tidak tergoyahkan karena sistem perbankan syariah menggunakan sistem bagi hasil, dan tidak berbasiskan pada bunga.

Jumlah lembaga keuangan syariah di Indonesia, baik dalam bentuk bank maupun non-bank, telah tumbuh dengan cukup pesat. Hal tersebut dapat dilihat dari jumlah lembaga keuangan syariah yang terus menerus bertambah setiap tahunnya. Hal ini imbas positif dari dikeluarkannya Undang-undang No.10 Tahun 1998, yang memungkinkan perbankan konvensional untuk melakukan dual banking system atau mendirikan divisi syariah (unit usaha syariah)

Unit Usaha Syariah menurut undang-undang No. 21 tahun 2008 adalah unit kerja dari kantor pusat Bank Umum Syariah yang berfungsi sebagai kantor induk dari kantor atau unit yang melaksanakan kegiatan usaha berdasarkan prinsip syariah, atau unit kerja di kantor cabang dari suatu bank yang berkedudukan di luar negeri yang melaksanakan kegiatan usaha secara konvensional yang berfungsi sebagai kantor induk dari kantor cabang pembantu syariah dan / atau unit syariah (Al Arif, 2012).

Keberadaan bank syariah sebagai bagian dari sistem perbankan nasional diharapkan mendorong perekonomian suatu negara. Tujuan dan fungsi perbankan syariah dalam perekonomian adalah kemakmuran ekonomi yang meluas, tingkat kerja penuh dan tingkat pertumbuhan ekonomi yang optimum, keadilan sosialekonomi, dan distribusi pendapatan serta kekayaan yang merata, stabilitas nilai uang, mobilisasi dan investasi tabungan yang menjamin adanya pengembalian yang adil dan pelayanan yang efektif (Setiawan, 2006)

Bagi kegiatan operasional bank syariah, hal yang mendasar yang harus diperhatikan adalah tetap memperhatikan keseimbangan antara memaksimalkan 
keuntungan dan pemenuhan prinsip syariah. Sesuai dengan Undang-Undang No. 21 Tahun 2008, perbankan syariah wajib menjalankan fungsinya baik fungsi intermediasi yang meliputi kegiatan penghimpunan dan penyaluran dana masyarakat untuk kepentingan menunjang pelaksanaan pembangunan sosial, juga fungsi sosial yang dilakukan dalam bentuk lembaga baitul mal yang dananya berasal dari zakat, infak, sedekah, hibah, ataupun dana sosial lainnya yang kemudian disalurkan kepada organisasi pengelola terkait

Tabel 1.Penyaluran Pembiayaan Perbankan Syariah (dalam miliar rupiah)

\begin{tabular}{cccccc}
\hline Akad & $\mathbf{2 0 1 1}$ & $\mathbf{2 0 1 2}$ & $\mathbf{2 0 1 3}$ & $\mathbf{2 0 1 4}$ & $\mathbf{2 0 1 5}$ \\
\hline Mudharabah & 10,229 & 12,023 & 13,625 & 14,307 & 14,820 \\
Musyarakah & 18,960 & 27,667 & 39,874 & 49,387 & 60,713 \\
Murabahah & 56,367 & 88,004 & 110,565 & 117,371 & 122,111 \\
Salam & 0 & 0 & 0 & 0 & 0 \\
Istisna & 326 & 376 & 582 & 633 & 770 \\
Ijarah & 3,839 & 7,345 & 10,481 & 11,620 & 10,631 \\
Qardh & 12,937 & 12,090 & 8,995 & 5,965 & 3,951 \\
Total & 102,655 & 147,505 & 184,122 & 199,330 & 203,996 \\
\hline
\end{tabular}

Sumber : Statistik Perbankan Syariah (diolah)

Fasilitas pembiayaan yang dilakukan oleh perbankan syariah harus memiliki peranan yang penting untuk menjaga stabilitas terhadap perkembangan sektor riil yang erat kaitannya dengan masyarakat kelas menengah ke bawah. Pembiayaan dengan prinsip bagi hasil diharapkan dapat lebih menggerakan sektor riil. Namun ternyata setelah sistem bagi hasil ini dipraktekkan dalam bentuk institusional LKS, sistem ini mengalami beberapa hambatan sehingga membuat pihak bank enggan menempatkan sebagian besar portfolio asetnya pada sistem bagi hasil ini. Sistem bagi hasil dianggap sangat berisiko, sehingga kemudian muncul alternatif pembiayaan murabahah yang dianggap lebih menguntungkan dan beresiko kecil. Sejak berkembangnya perbankan syariah di Indonesia, praktik murabahah di bank syariah memiliki kontribusi yang lebih tinggi dibandingkan musyarakah serta mudharabah. Tabel 1 adalah komposisi penyaluran pembiayaan yang diberikan Bank Umum Syariah dan Unit Usaha Syariah. Data Bank Indonesia 
menyebutkan tahun 2015 pembiayaan murabahah tercatat Rp. 122,111 miliar selanjutnya Mudharabah Rp, 14,820 miliar, Musyarakah Rp. 60,713 miliar, Istisna Rp770 miliar dan Ijarah Rp 10,631 miliar. Hal ini bahwa penyaluran pembiayaan perbankan syariah didominasi oleh pembiayaan Murabahah dari tahun ke tahun mengalami peningkatan serta menunjukan bahwa pembiayaan murabahah adalah produk yang paling diminati oleh nasabah.

Besarnya pengaruh beberapa faktor Internal terhadap pembiayaan Murabahah dapat diukur dengan beberapa rasio keuangan, diantaranya Dana Pihak Ketiga (DPK), dan Biaya Operasional terhadap Pendapatan Operasional (BOPO). Beberapa penelitian mengenai topik sejenis telah banyak dilakukan diantaranya oleh Husni (2010) dengan menggunakan variabel DPK, NPF, CAR, ROA, BOPO, Inflasi, Tingkat Suku Bunga, PDB. Dengan hasil DPK berpengaruh positif terhadap pembiayaan murabahah, sedangkan BOPO tidak berpengaruh terhadap Jumlah Pembiayaan. Sedangkan Katmas (2014) menunjukkan bahwa BOPO berpengaruh terhadap volume Pembiayaan.

Terdapat perbedaan pendapat tentang pengaruh DPK terhadap Pembiayaan murabahah. Hasil penelitian Hasan (2010) menunjukan bahwa DPK berpengaruh positif namun tidak signifikan terhadap pembiayaan murabahah, sedangkan berbeda dengan hasil penelitian dari Nurbaya (2013), Husni (2010), Arianti (2011), dan Rimadhani (2011) menunjukan bahwa DPK berpengaruh Positif Signifikan terhadap pembiayaan Murabahah. Setelah melihat beberapa penelitian terdahulu dapat ditemukan research gap dimana ada ketidakkonsistenan dalam setiap hasil penelitian, sehingga perlu dilakukan penelitian lebih lanjut.

\section{METODE}

Dalam penelitian ini adalah menganalisis pengaruh rasio keuangan yang berupa Biaya Operasional terhadap Pendapatan Operasional (BOPO) dan dana pihak ketiga (DPK) dari perbankan syariah terhadap jumlah pembiayaan murabahah di Indonesia. Penelitian ini bersifat kuantitatif atas data sekunder menggunakan data panel yaitu gabungan anatara data time series dan data cross section dalam kurun waktu 2011-2015. 
Data yang digunakan dalam penelitian ini adalah data sekunder yang berasal dari laporan keuangan triwulan Unit Usaha Syariah di periode tahun 20112015 yang dipublikasikan melalui internet, serta sumber-sumber lainnya yang relevan. Dalam penelitian ini metode pengumpulan data yang digunakan adalah dengan metode dokumentasi dengan cara mengumpulkan, mencatat, dan juga mengkaji data skunder yang berupa laporan triwulan publikasi Unit Usaha Syariah Periode 2011-2015 yang diperoleh dari situs OJK ( Otoritas Jasa Keuangan ) dan Unit Syariah terkait.

Populasi dalam penelitian ini adalah laporan keuangan triwulan dari Unit Usaha Syariah pada tahun 2011-2015. Untuk pengambilan sampel pada penelitian ini bersifat purposive sampling. yaitu Pengambilan sampel berdasarkan kriteria tertentu. Kriteria yang ditentukan oleh penulis dalam pemilihan sample bank syariah yaitu: (1) Unit Usaha Syariah milik BUMN, SWASTA dan BPD. (2) Bank telah mengeluarkan laporan keuangan triwulan. (3) Bank tersebut memiliki Jaringan Kantor Perbankan yang mudah dijangkau oleh nasabah.

Berdasarkan kriteria diatas, ada 5 UUS yang sesuai untuk dijadikan objek pada penelitian ini, yaitu Bank Tabungan Negara Syariah, Bank Permata Syariah, Bank CIMB Niaga Syariah, Bank DKI Syariah, dan Bank Kalimantan Barat Syariah. Pemilihan lima UUS ini antara lain: (1) Bank BTN Syariah Jumlah kantornya paling banyak sehingga mencangkup ke seluruh wilayahwilayah Indonesia dan karena satu satunya bank milik negara yang masih menjadi UUS. (2) Bank Permata Syariah dan Bank CIMB Niaga Syariah perwakilan dari milik swasta yang beroperasi di Indonesia. (3) Bank DKI Syariah dan Bank Kalimantan Barat Syariah karena keterwakilan dari BPD (Bank Pembangunan Daerah).

Teknik analisis data dalam penelitian ini adalah menggunakan analisis regresi data panel. Data panel adalah gabungan antara data runtut waktu (time series) dan data silang (cross section). Model regresi panel, sebagai berikut:

\section{Ln_Murabahah ${ }_{i t}=\alpha+\beta_{1} L_{-}{ }_{-D P K}$ it $+\beta_{2} \mathrm{BOPO}_{\text {it }}+\varepsilon_{\text {it }}$}




\section{HASIL DAN PEMBAHASAN}

Untuk mengetahui model panel yang akan digunakan, maka digunakan uji F-Restricted dengan cara melihat nilai (P-Value) F- Statistik lebih kecil dari tingkat signifikan $\alpha=5 \%$, terlebih dahulu dibuat hipotesisnya. Adapun hipotesisnya adalah sebagai berikut:

$\mathrm{H}_{0}$ : Model Pooled Least Square (PLS)

$\mathrm{H}_{1}$ : Model Fixed Effect (FEM)

Hasil Uji Chow menunjukkan nilai F-Statistik adalah 93.871242 dan nilai probabilitas F-Statistik sebesar 0.0000 yang berarti bahwa nilai probabilitas FStatistik lebih kecil dari tingkat signifikansi $\alpha 5 \%(0.0000<0.05)$. Maka $\mathrm{H}_{0}$ ditolak, sehingga model panel yang digunakan adalah Fixed Effect (FEM).

Untuk mengetahui model panel yang akan digunakan, maka digunakan uji hausman. Pengujian ini untuk menentukan model paling tepat digunakan antara Fixed Effet Model (FEM) dengan Random Effect Model (REM). Uji hausman memberikan penilaian dengan menggunakan Chi-Square Statistic dan nilai $\alpha 5 \%$ sehingga keputusan pemilihan model dapat ditentukan dengan tepat. Tabel Uji Hausman diperoleh Probabilitas 0,0363 yang berarti bahwa tingkat signifikansi $\alpha$ $5 \%(0,0363<0.05)$. Maka $\mathrm{H}_{0}$ ditolak, sehingga model panel yang digunakan adalah Fixed Effect (FEM).

Model data panel yang digunakan dalam penelitian ini adalah dengan menggunakan model Fixed Effect (FEM) dapat dijelaskan melalui persamaan sebagai berikut:

\section{Ln_Murabahah $=-\mathbf{- 0 . 7 0 0 6 9 0}+1.001557$ Ln_DPK -0.001911 BOPO}

Dimana: DPK : Dana Pihak Ketiga; BOPO : Biaya Operasional Pendapatan Operasional

Tabel 2 merupakan hasil pengujian variabel independen yaitu DPK dan BOPO terhadap Pembiayaan Murabahah secara parsial. Tabel 2 menunjukkan bahwa koefisien model regresi memiliki nilai konstanta sebesar -0.700690 dengan nilai $t$-statistic sebesar -0.842891 dan nilai probabilitas sebesar 0.4015 . Konstanta sebesar -0.700690 menandakan bahwa jika variabel independen konstan maka rata-rata Pembiayaan Murabahah adalah sebesar -0.700690. Hasil dari Tabel 2 
menunjukkan bahwa DPK berpengaruh positif terhadap Pembiayaan Murabahah. Nilai probabilitas sebesar 0.000, menunjukkan bahwa nilai probabilitas DPK < dari nilai $\alpha=5 \%$, maka $\mathrm{H}_{0}$ ditolak dan $\mathrm{H}_{\mathrm{a}}$ diterima. DPK memiliki nilai koefisien sebesar 1.001557. Hal ini menunjukkan jika DPK mengalami kenaikan 1 satuan, maka akan menaikkan Volume Pembiayaan Murabahah sebesar 1.001557 satuan, dengan catatan variabel lain dianggap konstan. Hasil dari Tabel 2 menunjukkan pula bahwa BOPO tidak berpengaruh signifikan terhadap Pembiayaan Murabahah. Nilai probabilitas sebesar 0.3134, menunjukkan bahwa nilai probabilitas BOPO > dari nilai $\alpha=5 \%$, maka $\mathrm{H}_{0}$ diterima dan $\mathrm{H}_{\mathrm{a}}$ ditolak. BOPO memiliki nilai koefisien sebesar 0.001911. Hal ini menunjukkan jika BOPO mengalami kenaikan 1 satuan, maka akan menaikkan Volume Pembiayaan Murabahah sebesar 0.01911 satuan, dengan catatan variabel lain dianggap konstan.

Tabel 2. Hasil Estimasi FEM

\begin{tabular}{ccccc}
\hline Variable & Koefisien & Std Error & t-statistics & Prob \\
\hline C & -0.700690 & 0.831293 & -0.842891 & 0.4015 \\
DPK & 1.001557 & 0.056865 & 17.61294 & 0.0000 \\
BOPO & 0.001911 & 0.001885 & 1.013613 & 0.3134 \\
R-squared & 0.958521 & F-statistic & & 358.1812 \\
Adj R-Squared & 0.955845 & Prob (F-Stat) & & 0.00000 \\
\hline
\end{tabular}

Sumber : Data diolah

Berdasarkan Tabel 2, hasil regresi data panel menggunakan Fixed Effect Model (FEM) diperoleh nilai F-statistik sebesar 358.1812 dengan nilai probabilitas sebesar 0.000000, pada tingkat keyakinan $\alpha=5 \%, k=3, n=100$, nilai F tabel df: $\alpha$, (k-1),(n-k) atau 0,05,(3-1),(100-3)= 2,97 sehingga diperoleh F-tabel dengan nilai df yaitu 3.09. Maka dapat dilihat bahwa F-statistik > F-tabel (358.1812> 3.09) atau nilai probabilitas F-statistik lebih kecil dari tingkat signifikansi $\alpha=5 \%(0.000000<$ 0.05). Hal ini menunjukkan bahwa Dana Pihak Ketiga (DPK) dan Biaya Operasional Pendapatan Operasional (BOPO) berpengaruh simultan terhadap pembiayaan Murabahah.

Tabel 2 menunjukkan nilai koefisien determinasi (adjusted $R^{2}$ ) sebesar 0.955845 atau 95.84\%. Dapat disimpulkan bahwa pengaruh Dana Pihak Ketiga (DPK) dan Biaya Operasional Pendapatan Operasional (BOPO) terhadap Pembiayaan Murabahah Unit Usaha Syariah adalah 95,84\%. Sedangkan sisanya 
sebesar 4.16\% (100\%-95,84\%) dipengaruhi oleh variabel-variabel lain yang tidak dimasukkan kedalam penelitian ini misalnya seperti Capital Adequacy Ratio (CAR), BI Rate, Giro Wajib Minimum (GWM), Financing to Deposit Ratio (FDR), Net Interest Margin (NIM), Non Performing Financing (NPF) dan lain-lain.Adapun angka koefisien determinasi menunjukkan nilai sebesar 0.955845 yang menandakan bahwa hubungan antara variabel dependen dan variabel independen adalah kuat karena memiliki nilai lebih dari0,5 $(\mathrm{R}>0,5)$ atau 0.955845>0,5.

Berdasarkan hasil estimasi, nilai probabilitas DPK adalah sebesar 0.0000 menunjukkan bahwa besarnya Dana Pihak Ketiga (DPK) berpengaruh secara signifikan pada taraf nyata 5\% ( = 5\%). Nilai koefisien yang dimiliki oleh DPK pada model yaitu sebesar 1.001557 yang berarti bahwa jika DPK naik sebesar 1\%, maka pembiayaan murabahah akan mengalami kenaikan sebesar 1.001557. Hal ini menunjukkan bahwa besarnya DPK yang dimiliki oleh bank syariah berpengaruh positif terhadap pembiayaan murabahah. Hasil penelitian ini sesuai dengan penelitian yang telah dilakukan oleh Arianti (2011), Rimadhani (2011) dan Ali (2016) menunjukkan bahwa H1 terbukti. Dana merupakan masalah utama bagi bank termasuk bank syariah, tanpa dana yang mencukupi bank tidak dapat melakukan aktivitasnya atau bahkan tidak berfungsi sama-sekali. Dana Pihak Ketiga (DPK) merupakan dana yang dihimpun dari masyarakat yang merupakan dana terbesar yang paling diandalkan oleh bank. Jika DPK yang dimiliki oleh bank bertambah, maka budget bank juga akan bertambah. Dana tersebut akan dialokasikan oleh bank dengan berbagai bentuk penyaluran termasuk untuk pembiayaan. Teori mengatakan bahwa semakin banyak DPK yang berhasil dihimpun oleh suatu bank, maka akan semakin banyak pula pembiayaan yang dapat disalurkan oleh bank tersebut termasuk pembiayaan murabahah.

Variabel BOPO memiliki nilai koefisien -0.001911, hal ini berarti $\mathrm{H}_{0}$ diterima dan Ha ditolak, maka dapat disimpulkan bahwa variabel BOPO tidak berpengaruh terhadap pembiayaan murabahah di UUS. Hal ini disebabkan karena tingkat efisiensi bank dalam menjalankan operasinya berpengaruh terhadap pendapatan yang dihasilkan oleh bank tersebut. Dapat dilihat pada data penelitian, bahwa rata-rata rasio BOPO yaitu 37.79\%. Ketetapan dari OJK untuk rasio BOPO adalah dibawah 90\%, hal ini berarti bahwa BTN Syariah periode Juni 2011 sangat 
efisien dalam melakukan kegiatan operasionalnya dengan nilai minimum 2,76\%. Jika kegiatan operasional dilakukan dengan efisien (dalam hal ini rasio BOPO rendah) maka pendapatan yang dihasilkan bank tersebut akan naik. Selain itu, besarnya rasio BOPO juga disebabkan karena tingginya biaya dana yang dihimpun dan rendahnya pendapatan bunga dari penanaman dana sehingga semakin besar BOPO maka akan semakin kecil pembiayaan murabahah yang disalurkan. Hasil penelitian mendukung hasil penelitian yang dilakukan oleh Ali (2016) menyimpulkan bahwa BOPO tidak berpengaruh terhadap Jumlah Pembiayaan. BOPO memberikan indikasi bahwa apabila manajemen mampu menekan BOPO yang berarti efisiensi meningkat akan sangat signifikan terhadap kenaikan penyaluran dana pembiayaan murabahah.

\section{SIMPULAN}

Dari hasil analisis data yang telah dilakukan dalam penelitian ini, dapat disimpulkan bahwa faktor-faktor yang memengaruhi pembiayaan murabahah pada unit usaha syariah adalah DPK. Pengujian variabel faktor-faktor tersebut yang dilakukan dengan menggunakan data panel Fixed Effect Model (FEM) menunjukkan seluruh variabel secara bersama-sama memiliki pengaruh yang signifikan pada taraf nyata 5 persen terhadap pembiayaan murabahah. Secara parsial variabel DPK berpengaruh signifikan dan positif terhadap pembiayaan murabahah. Sedangkan untuk variabel BOPO tidak berpengaruh terhadap pembiayaan murabahah di Unit Usaha Syariah.

\section{PUSTAKA ACUAN}

Al Arif, M. NR. (2012). Lembaga Keuangan Syariah, Bandung: CV Pustaka Setia.

Ali, H \& Miftahurohman. (2016). Determinan yang Mempengaruhi Pembiayaan Murabahah pada Perbankan Syariah di Indonesia. Esensi: Jurnal Bisnis dan Manajemen. Volume 6 (1): 31-44.

Hakim, L. (2012) Prinsip-Prinsip Ekonomi Islam. Yogyakarta: Erlangga.

Hasan, S. (2015). Pengaruh Dana Pihak Ketiga, dan Pembiayaan Murabahah terhadap Financing Deposit Ratio PT BANK MUAMALAT INDONESIA TBK. (Skripsi Tidak Dipublikasikan). Universitas Negeri Gorontalo. 
Husni. (2010). Pengaruh Tingkat DPK, SWBI, dan NPF Terhadap Penyaluran Pembiayaan Pada Bank Muamalat Indonesia: Periode 2001-2008. (Skripsi Tidak Dipublikasikan). Universitas Islam Negeri Sunan Kalijaga.

Kasmir. (2006). Manajemen Perbankan. Jakarta: PT Raja Grafindo Persada.

Katmas, E. (2014). Pengaruh Faktor Eksternal dan Internal terhadap Volume Pembiayaan Perbankan Syariah Di Indonesia. (Skripsi Tidak Dipublikasikan). Universitas UIN Syarif Hidayatullah.

Nurbaya, F. (2013). Analisis Pengaruh CAR, ROA, FDR, dan Dana Pihak Ketiga (DPK) Terhadap Pembiayaan Murabahah. (Skripsi Tidak Dipublikasikan). Universitas Diponegoro.

Rimadhani, M \& 0. Erza. (2011). Analisis Variabel Variabel yang Mempengaruhi Pembiayaan Murabahah Pada BSM: Periode 2008.01-2011.12. Jurnal Media Ekonomi. Volume 19 (1): 27-40.

Setiawan, A.A. (2006). Perbankan Islami Challenges dan Opportunity untuk pengembangan di Indonesia. Jurnal Kordinat. Volume VIII, No 1: 1-15.

Wuri, A.N.P. (2011). Analisis Pengaruh DPK, CAR, NPF dan ROA Terhadap Pembiayaan Pada Perbankan Syariah Studi Kasus BMI: Periode 2001-2011. (Skripsi Tidak Dipublikasikan). Universitas Diponegoro. 